Jurnal Pengajian Melayu - JOMAS, Jilid 32(1), 2021: 105-117

\title{
HUBUNGAN ALAM DAN MANUSIA DALAM FILEM TOMBIRUO: PENUNGGU RIMBA (2017)
}

\author{
(RELATIONSHIP BETWEEN NATURE AND MAN IN TOMBIRUO: \\ PENUNGGU RIMBA (2017) \\ Nur Afifah Vanitha Abdullah \\ nurafifah@ukm.edu.my \\ Fatimah Muhd Shukri \\ fatimahmuhdshukri@gmail.com \\ Nur Aifaa Nabilah Mohd Rosdi \\ effarosdi93@gmail.com \\ Universiti Kebangsaan Malaysia, Bangi \\ Malaysia
}

Received: 5 December 2021; Accepted: 8 April 2021

\begin{abstract}
'Tombirou: Penunggu Rimba'(2017) (TPR) is a mystical action film based on the rural Sabahan community belief about nature. More than 99 per cent of this film was shot in forested areas, therefore relevant to the film's ultimate idea, which is the importance of caring for nature and striking that balance between nature and man. The film also contains symbolism that conveys nature's revenge against man for their irresponsibility. Thus, this paper studied the portrayal of man and nature in TPR. An approach was devised with content analysis as a tool to answer the said question. This was supported by applying Aldo Leopold's ecocentrism (1949) to analyse the film. The primary research material was TPR, whilst additional data was retrieved from books, journal articles and newspaper articles. Findings showed that this film had portrayed the importance of preserving the balance between nature and man in life's ecosystem. This factor is vital to ensure nature's wellness and the balance between man and nature. The characters Tombiruo, Tobugi, Bobolian and Pondolou were also shown as agents of peace, mediators and caretakers of nature.
\end{abstract}

Keywords: ecocentrism, Tombiruo: Penunggu Rimba, Malay film, film criticism, symbolism. 


\begin{abstract}
Abstrak
Filem Tombiruo: Penunggu Rimba (2017) (TPR) bergenre aksi mitos dan disandarkan kepada kepercayaan masyarakat pedalaman di Sabah mengenai semangat alam. Lebih 99 peratus latar tempat dalam filem ini adalah hutan. Hal ini sesuai dengan persoalan utama filem ini, iaitu kepentingan menjaga kesejahteraan dan keseimbangan antara alam dan kehidupan manusia. Filem ini juga sarat dengan simbolisme bagi memaparkan balasan alam terhadap perbuatan manusia yang tidak bertanggungjawab terhadapnya. Makalah ini bertujuan meneliti pemaparan alam dan manusia sebagai subjek dalam filem TPR. Sehubungan itu kajian fundamental direkabentuk, dengan mengaplikasi analisis kandungan untuk merungkai persoalan kajian "bagaimana subjek alam dan manusia dipaparkan dalam filem TPR?" Penelitian ini mengaplikasikan pendekatan ekosentrisme yang dikemukakan oleh Aldo Leopold (1949) bagi menjawab persoalan makalah ini. Antara bahan kajian yang diteliti bagi memperoleh data adalah buku, artikel jurnal dan akhbar. Bahan utama kajian adalah filem TPR. Dapatan menunjukkan filem ini memaparkan isu kepentingan memelihara keseimbangan antara alam dan manusia dalam ekosistem kehidupan. Aspek ini penting untuk menjamin kesejahteraan dan kesinambungan manusia serta alam. Watak Tombirou, Tobugi, bobolian, dan Pondolou juga dipaparkan sebagai agen pendamai dan penghubung serta pemelihara alam.
\end{abstract}

Kata Kunci: ekosentrisme, Tombiruo: Penunggu Rimba, filem Melayu, kritikan filem, simbolisme.

\title{
Pengenalan
}

Filem Tombiruo: Penunggu Rimba (2017) (TPR selepas ini) adalah sebuah karya adaptasi daripada novel yang berjudul Tombiruo, karya Ramlee Awang Murshid (Naque Ariffin, 2017 \& Nina Farzuin, 2014). Filem $T P R$ bergenre aksi mitos, iaitu sebuah cerita yang disandarkan kepada kepercayaan masyarakat pedalaman di Sabah mengenai semangat hutan. Filem ini diterbitkan dengan anggaran kos produksi Ringgit Malaysia Enam Juta. Lokasi utama TPR adalah hutan Keningau, Sabah, dan membariskan pelakon lama dan baharu di Malaysia antaranya, Zul Ariffin, Farid Kamil, Nabila Huda, Faizal Hussein, M. Nasir, Marlia Musa dan Farah Ahmad (Malay Mail, 2017; Shazryn, 2017 \& Astro Awani 2017).

Plot filem TPR dimulakan dengan watak Monsiroi atau Bobolian, iaitu bomoh bagi masyarakat pedalaman Sabah. Adegan ini adalah pengalaman silam Bobolian membantu seorang gadis bernama Tobugi untuk melahirkan kandungannya. Tobugi mengandung kerana diperkosa oleh Tarawid, lelaki sekampung Tobugi. Pada saat Tobugi melahirkan kandungannya, Tarawid cuba membunuh Tobugi untuk menghapuskan perbuatan jahatnya. Namun begitu usahanya gagal kerana Bobolian membunuh Tarawid terlebih dahulu. Tobugi juga meninggal dunia selepas bersalin. Monsiroi kemudiannya menghanyutkan anak Tobugi di sungai yang berdekatan dan tangisan bayi itu seolah-olah menghidupkan semangat hutan. Pondolou, seorang bekas askar British yang hidup di hutan tersebut terdengar tangisan bayi dan menyelamatkannya. Pondolou membesarkan bayi tersebut dengan nama, Ejim atau Tombiruo. Sejak kecil, Pondolou mendidik Ejim untuk menjaga hutan. Apabila semakin dewasa, watak ini mempertahankan hutan daripada manusia yang tidak bertanggungjawab, rakus, dan mengganggu gugat kesinambungan serta kesejahteraan alam.

Filem $T P R$ adalah antara filem Melayu yang mengangkat alam sebagai subjeknya (Ahmad Zamil et. al., 2013). Filem ini mengangkat isu tindakan sesetengah manusia yang rakus dengan alam sekitar tanpa mempedulikan ekosistem yang stabil antara alam sekitar dan manusia. Mesej utama TPR adalah keharmonian antara manusia dan alam akan tergugat, apabila manusia bertindak sebagai perosak. Kesannya adalah ekosistem akan terganggu dan seterusnya menimbulkan kesan negatif terhadap manusia. Sehubungan 
dengan itu, objektif makalah ini adalah untuk mengupas filem $T P R$ dengan mengaplikasi pendekatan ekosentrime bagi menjawab persoalan, "bagaimana subjek alam dan manusia dipaparkan dalam filem $T P R$ untuk menyampaikan mesej filem ini?”

\section{Sorotan Kajian}

Setakat ini hanya terdapat dua penulisan lepas tentang filem TPR. Kedua-dua penulisan ini berbentuk penulisan ilmiah, iaitu artikel jurnal. Artikel pertama dihasilkan oleh Hani Salwah Yaakup (2018), manakala artikel kedua pula dihasilkan oleh Nur Aifaa, Nur Afifah, dan Fatimah Shukri (2020). Artikel pertama membincangkan aspek kebudayaan masyarakat Kadazan-Dusun dalam filem $T P R$, manakala artikel kedua pula menerangkan proses transformasi naratif novel Tombiruo (2007) ke filem TPR (2017).

Makalah Hani Salwah Yaakup (2018) dalam 'Tombiruo: Adaptasi Novel ke Filem dan Representasi Kepercayaan Setempat' meneliti kepercayaan spiritual masyarakat Kadazan-Dusun yang telah direpresentasikan dalam filem TPR. Permasalahan makalah ini adalah naskhah yang diadaptasi seringkali diselar kerana tidak mampu mengangkat jalan penceritaan yang sama dengan novel, khususnya melalui ketidaktepatan representasi budaya. Maka, makalah ini menjawab persoalan, iaitu bagaimana kepercayaan spiritual yang cuba direpresentasikan dalam filem TPR? Makalah ini juga mengaplikasikan kaedah penyelidikan kualitatif bersifat deskriptif dengan membuat perbandingan dari aspek unsur naratif antara novel dengan filem. Dapatan menunjukkan filem ini tidak menvisualkan dengan jelas berkenaan dengan kepercayaan dan adat masyarakat Kadazan-Dusun serta penjelasan mengenai plot dan sebab akibat watak bertindak dalam sesuatu babak berkenaan kepercayaan masyarakat Kadazan Dusun tidak diperincikan dengan jelas. Makalah oleh Hani Salwah Yaakup meneliti filem TPR dalam konteks kepercayaan masyarakat Kadazan-Dusun yang telah direprensentasikan dalam filem tersebut. Perbezaan antara artikel ini dengan makalah Hani Salwah adalah dari segi fokus kajian dan kerangka kajiannya. Fokus artikel ini adalah hubungan antara alam dan manusia, manakala kerangka pendekatannya pula adalah ekosentrisme.

Artikel jurnal Nur Aifaa Nabila et. al., (2020), bertajuk, 'Proses Transformasi Naratif Daripada Novel ke filem TPR (2017). Makalah ini bertujuan menjawab persoalan: "apakah proses transformasi yang dilalui oleh naratif filem $T P R$ apabila diadaptasi daripada novel ke filem?" Data bagi makalah ini diperoleh daripada penyelidikan jenis fundamental dengan kaedah kualitatif. Instrumen utama bagi memperoleh data adalah analisis kandungan terhadap novel dan filem TPR. Antara sumber rujukan kajian ini adalah artikel jurnal, buku, bab dalam buku, disertasi, majalah, dan akhbar. Artikel ini mengaplikasi prinsip transformasi, 'teori intertekstualiti' yang dikemukakan oleh Julia Kristeva sebagai kerangka analisis. Dapatan menunjukkan sebahagian besar naratif novel dipindahkan oleh pengarah ke filem. Namun begitu, perubahan yang signifikan tetap dilakukan pada plot dan watak. Hal ini terpaksa dilakukan kerana filem berbentuk audio visual. Filem memiliki sifat berbeza berbanding dengan novel kerana gaya naratif novel tidak mungkin dapat digarap secara mutlak ke bentuk filem. Oleh yang demikian, naratif sebuah novel harus melalui proses transformasi untuk dipersembahkan dalam bentuk filem. Subjek makalah Nur Aifaa et al. lebih tertumpu kepada proses transformasi naratif novel ke filem TPR. Hal ini berbeza dengan artikel ini yang menjurus kepada penelitian terhadap perhubungan alam dan manusia dalam filem $T P R$. 


\section{Metodologi}

Data bagi makalah ini diperolehi daripada kajian jenis penyelidikan fundamental dengan kaedah kualitatif sebagai reka bentuk kajian. Kaedah utama untuk memperoleh data adalah melalui analisis kandungan. Bahan utama yang diteliti dan menjadi sandaran adalah filem $T P R$ dan bahan lain seperti buku, artikel jurnal, artikel akhbar serta majalah.

Pendekatan ekosentrisme yang telah dirangka akan diaplikasikan untuk menjawab persoalan kajian ini. Pendekatan ini telah dipelopori oleh Aldo Leopold pada tahun 1949 (Eckersley 1992). Ekosentrisme adalah salah satu terma dalam bidang falsafah politik ekologi. Pendekatan ini berpaksi pada alam semulajadi dan bukannya manusia dalam konteks sistem nilai. Fokus pada ekosentrisme ini disandarkan kepada kepercayaan bahawa manusia adalah sama penting dengan semua jenis kehidupan di alam semesta. Manusia dan segala kehidupan mendiami satu ekosistem yang saling bergantungan dan berkepentingan antara satu dengan yang lain (Bosselmann, K. 1999).

\section{Dapatan}

Masyarakat dalam filem $T P R$ adalah sekumpulan manusia yang bergantung dan hidup aman dengan alam. Kumpulan manusia ini menghormati dan menghargai alam sebagai sumber kehidupan mereka. Kebergantungan ini berkait rapat dengan fenomena alam seperti malam dan siang, angin, kilat dan petir serta hujan. Justeru, artikel ini bertujuan untuk mengupas perhubungan latar tempat dan masyarakat dengan alam serta simbolisme sifat alam pada watak serta perwatakan dalam filem TPR. Kupasan ini dibahagikan kepada beberapa komponen, iaitu latar tempat, latar masyarakat, watak dan perwatakan. Komponen-komponen ini dikupas bersandarkan pendekatan ekosinterisme bagi menghuraikan hubungan manusia dengan alam sekitar, iaitu yang pertama dari sudut latar filem. Latar filem dibincangkan dari aspek latar tempat dan latar masyarakat. Sudut kedua pula adalah dari aspek watak dan perwatakan dalam filem TPR.

\section{Latar Tempat}

Lokasi filem TPR adalah 99 peratus hutan (Syanty Octavia, 2017). Hanya satu peratus dari latar tempat dalam filem ini adalah di luar kawasan hutan. Satu peratus ini merupakan latar tempat di rumah Tan Sri Berham, tanah perkuburan di Masjid Jamek At-Tahniah dan kilang papan. Lokasi penggambaran hutan belantara TPR berlatarbelakangkan Gunung Kinabalu dan beberapa lokasi lain di Sabah, Sarawak dan Selangor. Antara lokasi alam bagi penggambaran filem TPR di Sabah adalah Kinabalu Pine Resorts, Sabah; dan Chongkak Park and Resort serta Nur Lembah Pangsun, Hulu Langat di Selangor. Lokasi-lokasi ini masih mengekalkan keindahan alam seperti sungai serta flora dan fauna. Hal ini bermakna penggambaran filem TPR telah mengambil tempat di lokasi hutan sebenar.

Hutan belantara adalah latar utama dalam filem TPR. Menurut kepercayaan masyarakat pedalaman yang mendiami hutan Keningau, hutan memiliki semangat atau penunggu (Hani Salwah Yaakup, 2018). Semangat 'penjaga' ini akan terganggu jika hutan dicerobohi oleh manusia yang berniat jahat, terutamanya golongan yang ingin mengaut keuntungan dengan mengakibatkan kemusnahan alam. Situasi ini dapat dikesan daripada dialog Pondolou "hutan kita semakin sempit", pada minit ke 14:56. Dialog ini memberi indikasi bahawa keluasan kawasan hutan semakin mengecil disebabkan aktiviti manusia yang mahukan pembangunan. Hal ini termasuk projek empangan yang dirancang di kawasan hutan kediaman Tombiruo 
selaku 'penjaga' hutan tersebut dan komunitinya.

Hubungan alam semulajadi dengan masyarakat pedalaman di Sabah adalah sangat akrab dan bergantungan. Masyarakat ini juga mengadakan upacara tahunan khusus untuk menghargai dan menghormati alam, iaitu perayaan pesta keamatan. Pesta ini bertujuan menghormati roh atau semangat beras (Kerajaan Negeri Sabah, 2020). Dalam filem $T P R$, orang luar merosakkan hutan dan perbuatan ini tidak menghormati kepercayaan masyarakat tempatan yang hidup harmoni dengan alam. Semangat alam yang mendukung pelbagai kehidupan dan khazanah diceroboh dan dinodai oleh golongan ini. Umum mengetahui bahawa khazanah hutan flora dan fauna yang khusus serta istimewa terdapat di sesuatu kawasan hutan sahaja. Misalnya, bunga terbesar di dunia, iaitu Rafflesia atau Bunga Pakma hanya tumbuh dan terdapat di hutan belantara di Sabah, Sarawak dan beberapa tempat di Indonesia. Khazanah fauna seperti orang utan juga hanya terdapat di lokasi ini. Oleh itu, manusia perlu memelihara dan memastikan kelestarian khazanah hutan ini. Dalam filem $T P R$, hal ini merupakan salah satu sebab Tan Sri Berham menarik diri daripada pembinaan projek empangan. Selain itu, projek empangan tersebut juga didapati melibatkan kehilangan tempat tinggal bagi 10,000 ribu penduduk asalnya. Tindakan Tan Sri Berham ini memaparkan tindakan yang harus dipuji kerana keputusan tersebut disandarkan kepada perasaan hormat dan sayangkan khazanah alam. Kehidupan, masa depan dan kelestarian khazanah alam diberi keutamaan berbanding dengan kekayaan peribadi.

Selain menarik diri daripada projek empangan, Tan Sri Berham juga mengadakan sidang media bagi membantah pembinaan projek empangan tersebut. Watak-watak penduduk asal juga turut hadir dalam sidang media tersebut. Watak-watak ini mengadvokasi supaya alam sekitar dan khazanahnya harus dilindungi dan dijaga untuk generasi akan datang. Mereka membantah tindakan sesetengah pihak yang menceroboh dan mengeksploitasi alam. Penduduk asal membantah pembangunan empangan kerana akan memusnahkan budaya, khazanah dan warisan nenek moyang mereka. Pembangunan seperti ini akan turut memberi kesan negatif terhadap ilmu kearifan lokal di kawasan tersebut. Ilmu flora dan fauna, perubatan, teknik 'survival', kesenian dan kebudayaan setempat akan pupus apabila mereka terpaksa meninggalkan kehidupan turun temurun mereka. Tradisi dan kebudayaan yang mereka warisi juga akan terhapus apabila masyarakat pedalaman ini ditempatkan di suatu lokasi lain.

Apabila manusia rakus dalam mengejar pembangunan, kepentingan alam dalam menjamin ekosistem yang seimbang akan terpinggir. Dalam filem $T P R$, segelintir komuniti luar rakus dan pentingkan keuntungan peribadi, lalu menyebabkan kemusnahan kekal kepada alam sekitar. Sebagai contoh, perbuatan rakus dipaparkan menerusi watak Juslan yang sanggup membunuh abang kandungnya, iaitu Tan Sri Berham dan Salina anak saudaranya kerana sifat tamak Juslan yang mahu mengaut keuntungan daripada projek empangan di hutan Keningau. Hal ini bertentangan dengan kepercayaan masyarakat pedalaman bahawa manusia harus memelihara kesejahteraan alam agar hubungan damai antara manusia dan alam terjamin. Balasan kepada niat jahat golongan ini adalah balasan daripada Tombiruo, watak simbolik kepada semangat hutan Keningau. Watak Juslan dan Wong yang banyak melakukan kerosakan alam seperti penebangan hutan, membina projek empangan dan merosakkan ekosistem hutan; akhirnya mereka berdua dihukum mati oleh alam. Juslan menemui ajal apabila terjatuh ke dalam rekahan tanah dan Wong pula mati di tempat kejadian apabila ditindih pokok. Kedua-dua watak antogonis ini mati di hutan dalam keadaan kemalangan semulajadi.

\section{Masyarakat dan Hubungan Alam}

Masyarakat filem TPR terdiri daripada dua kelompok. Kelompok pertama ialah masyarakat di hutan, dan kelompok kedua ialah masyarakat bandar. Kehidupan kelompok masyarakat pertama amat bergantung 
kepada alam semula jadi. Kelompok ini terdiri daripada masyarakat pedalaman yang terdiri daripada Pondolou, anak angkatnya Ejim, Bobolian dan masyarakat kampung pedalaman. Kelompok kedua terdiri daripada keluarga Tan Sri Berham, Wan Suraya dan Wong. Antara kedua-dua kelompok masyarakat ini, hanya masyarakat pedalaman di Sabah yang memaparkan hubungan rapat dengan alam sekitar. Masyarakat ini amat bergantung kepada hutan untuk kelangsungan kehidupan seharian mereka. Sementara itu, masyarakat bandar dalam filem $T P R$ pula sebahagian besarnya digambarkan sebagai golongan yang mengganggu ekosistem alam di hutan Keningau, iaitu Juslan dan koncu-koncunya. Walau bagaimanapun watak Tan Sri Berham, Salina, Bonda, dan Wan Suraya dari bandar terkecuali daripada sikap rakus terhadap alam. Mereka berusaha melindungi hutan serta khazanahnya. Sehubungan dengan itu, perbincangan tentang masyarakat $T P R$ dikupas dari aspek budaya, pakaian dan pekerjaan bagi kelompok masyarakat pedalaman.

Pemerincian budaya masyarakat pedalaman dalam filem $T P R$, dibincangkan dalam konteks adat dan kepercayaan masyarakat ini. Masyarakat pedalaman $T P R$ kaya dengan adat dan kepercayaan khususnya yang berkait dengan semangat alam (Low, 2005 \& Hani Salwah 2018). Dalam filem TPR, antara kepercayaan masyarakat yang menetap di hutan Keningau adalah bahawa Tombiruo merupakan penjaga alam, pembayaran sogit bagi sesiapa yang melakukan kesalahan dan Bobolian sebagai pengantara dua alam, iaitu alam manusia dan roh. Tiga kepercayaan ini mendasari kehidupan masyarakat pedalaman pagan (Suraya Sintang, 2003).

Tombiruo dipercayai sebagai semangat atau roh yang bangkit sebagai hantu jika pengebumian gagal dilakukan dengan sempurna mengikut ritual tradisi masyarakat ini (Pugh-Kitigan, 2016 \& Hani Salmah, 2018). Walau bagaimanapun, dalam filem $T P R$, Tombiruo adalah kesan perbuatan jahat yang dilakukan oleh Tarawid kepada alam, iaitu Tobugi. Tombiruo adalah semangat alam seperti yang dipercayai oleh masyarakat pedalaman. Watak ini ditampilkan dalam dalam bentuk dan sifat manusia. Oleh itu, masyarakat pedalaman dalam filem TPR percaya bahawa Tombiruo adalah penyelamat mereka. Hal ini berbeza dengan masyarakat bandar yang menggeruni watak Tombiruo sebagai hantu. Wajah buruk Tombiruo adalah simbol dan kesan kejahatan, kemusnahan serta keburukan manusia terhadap alam.

Sogit (denda) menurut adat kepercayaan masyarakat pedalaman adalah ganti rugi atau denda jika suatu kesalahan dilakukan oleh mana-mana ahli masyarakat ini (Minah Sintian, 2013). Pembayaran sogit harus dilakukan bagi mengelak sebarang bencana dan menebus kesalahan manusia yang melakukan kerosakan ke atas alam (Minah Sintian, 2013). Dalam filem TPR, pembayaran sogit dilaksanakan oleh Monsiroi selepas melahirkan anak Tobugi. Sogit ini dibayar dengan menghayutkan Tombiruo (ketika bayi) ke sungai dan menyerahkan Amiruddin bersama-sama seekor kerbau kepada penduduk kampung. Perbuatan Monsiroi ini bertujuan menebus dosa Tarawid yang memperkosa Tobugi, agar keharmonian alam dijaga.

Fungsi Bobolian dalam masyarakat pedalaman adalah sebagai agen penghubung antara alam ghaib dengan alam nyata. Menurut kepercayaan masyarakat pedalaman, Bobolian mampu berkomunikasi dengan alam ghaib untuk menyelesaikan masalah yang mereka hadapi, misalnya penyakit kronik atau bencana alam (Suraya Sintang, 2003). Dalam filem TPR, Monsiroi bertanggungjawab menyembunyikan Tobugi yang hamil akibat perbuatan Tarawid. Monsiroi juga membantu Tobugi melahirkan anak kembarnya dan membunuh Tarawid. Disebabkan bimbang perbuatannya menjadi punca malapetaka ke atas penduduk kampung, Bobolian membawa diri dan tinggal berseorangan di kawasan terpencil jauh di pedalaman. Kenyataan ini bersandarkan pada dialog pada minit ke 45:47 oleh Ondu kepada Amiruddin, iaitu "Aku rasa dialah Monsiroi, Bobolian yang telah lama menghilangkan diri”. Kemudian Ondu menyapa Monsiroi dalam bahasa etnik masyarakat pedalaman yang bermaksud "Adakah awak ini Monsiroi?". Dalam konteks ini, watak Bobolian ini turut menghukum dan mengenakan sogit terhadap dirinya bagi menjaga dan 
mengekalkan keharmonian antara alam dan manusia.

Topeng adalah sebagaian daripada pakaian bagi watak Tombiruo. Watak ini mengenakan topeng sepanjang filem ini kerana wajahnya tidak sempurna. Topeng Tombiruo diperbuat daripada pokok kayu. Bahan topeng ini adalah simbol watak ini dan hubungannya dengan alam semula jadi. Hal ini demikian kerana, watak ini lahir dan dibesarkan dalam hutan serta kehidupannya bergantung sepenuhnya kepada sumber alam. Sehubungan dengan itu, topeng Tombiruo diukir dengan sifat wajah manusia yang lengkap dengan lubang mata, hidung, mulut dan kening.

Tombiruo mengenakan tiga topeng berbeza sepanjang jalan cerita. Topeng pertama adalah semasa zaman kanak-kanaknya, kedua; topeng yang dipakai pada waktu sekarang, iaitu Tombiruo dewasa dan ketiga; topeng baharu yang diukir sendiri oleh Tombiruo. Topeng ketiga ini amat berbeza jika dibandingkan dengan topeng pertama dan kedua. Perbezaannya adalah dari segi kematangan dan ekspresi topeng yang dipakai oleh Tombiruo sepanjang filem. Topeng pada zaman kanak-kanaknya menunjukkan permukaan yang licin dengan garisan halus. Topeng tersebut lebih berupa wajah kera yang menampakkan dahi, mulut dan hidung. Sementara itu, topeng Tombiruo dewasa pula lebih jelas memaparkan rekahan berbanding dengan topeng zaman kanak-kanaknya. Topeng ketiga pula lebih mirip wajah manusia dengan garis rekahan lebih dalam serta menampakkan bentuk mulut, kening dan hidung.

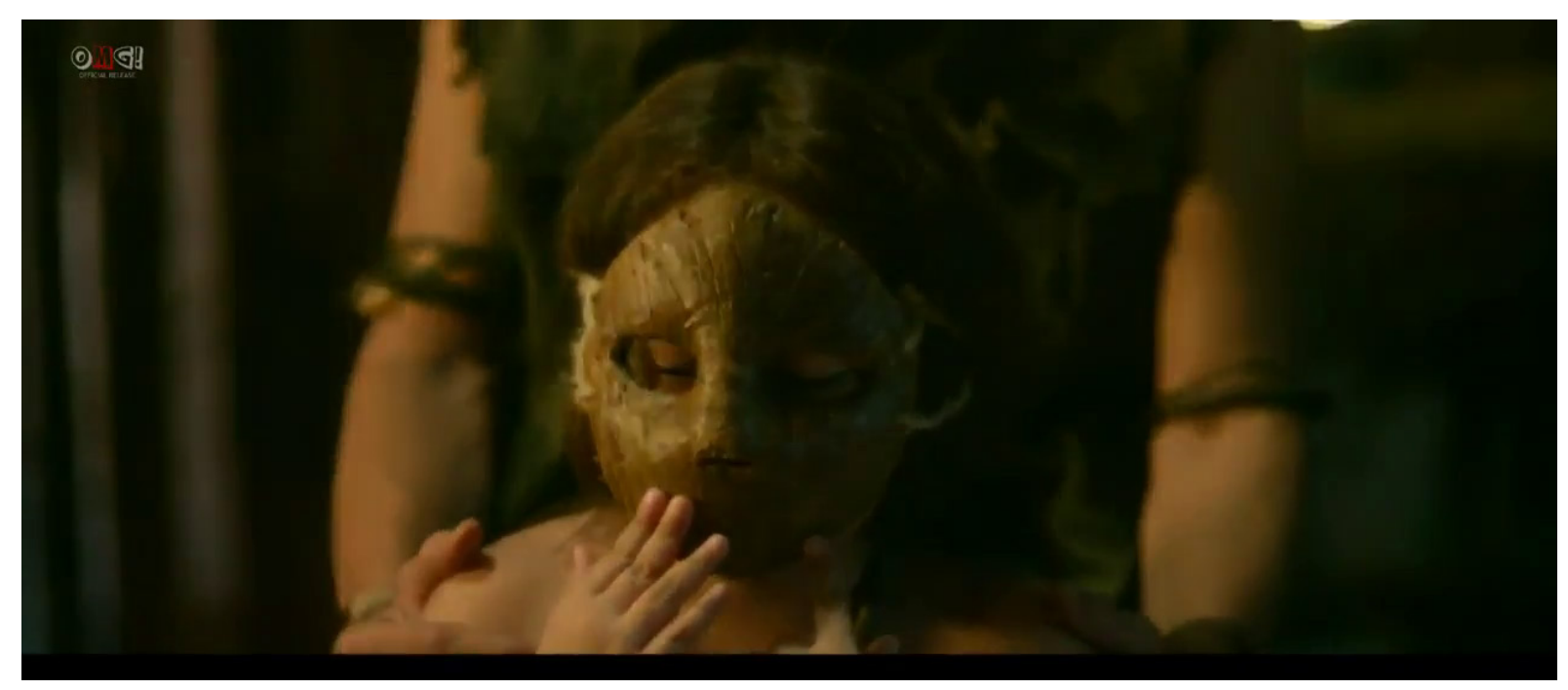

Gambar 1: Topeng pertama Tombiruo semasa kanak-kanak. 


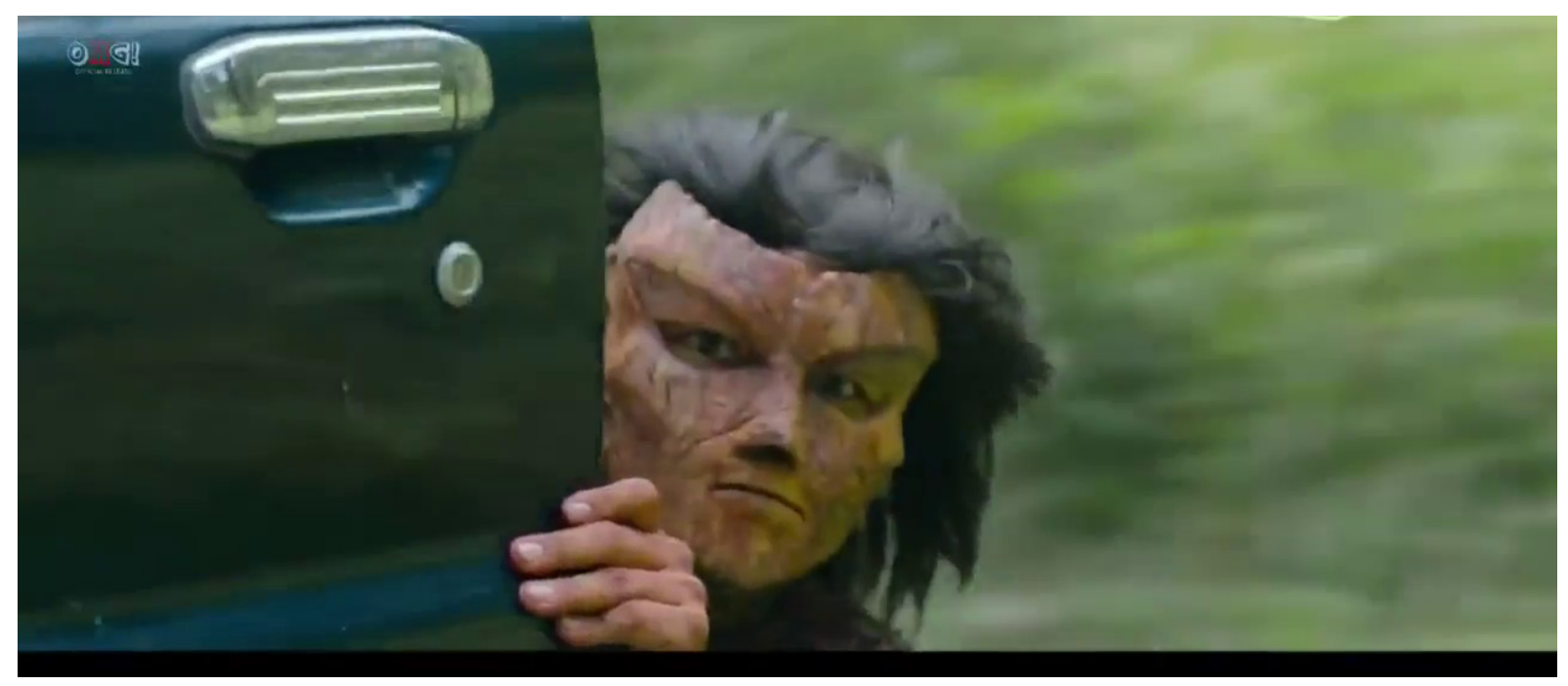

Gambar 2: Topeng Kedua Tombiruo.

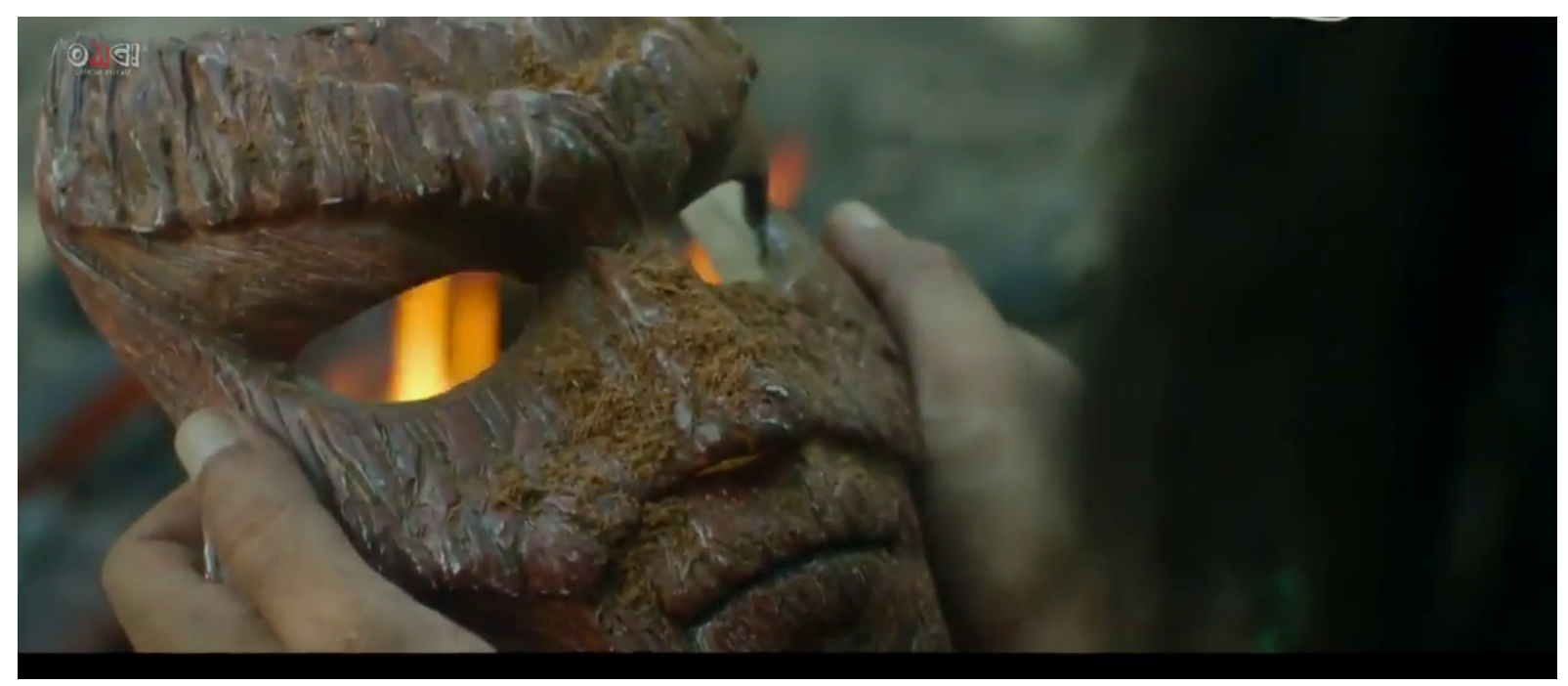

Gambar 3: Topeng Ketiga Tombiruo.

Kehidupan masyarakat pedalaman dalam filem TPR sangat bergantung kepada sumber alam sekitar. Masyarakat ini memiliki kearifan lokal dalam memelihara dan melestarikan alam sekitar (Minah Sintian, 2013). Kearifan lokal dikaitkan dengan budaya tertentu dan mencerminkan kehidupan sebuah masyarakat. Hal ini dipaparkan melalui aktiviti mereka seperti penternakan dan menangkap ikan. Misalnya, Pondoluo menggunakan serkap, iaitu sejenis alat yang diperbuat daripada buluh untuk menangkap ikan di sungai. Monsiroi memberi seekor kerbau kepada seorang penduduk kampung sebagai bayaran sogit, manakala watak Pondolou pula dipaparkan sedang menangkap ikan ketika menemui bayi yang dihanyutkan di sungai. Selain itu, aktiviti menangkap ikan dan penternakan, seluruh kehidupan masyarakat pedalaman KadazanDusun dalam filem ini menunjukkan kebergantungan kepada alam sekitar. Bagi meneruskan kelangsungan hidup, masyarakat Kadazan-Dusun mencari sumber alam yang terdapat di persekitaran mereka untuk mendirikan rumah. Perkara ini jelas dipaparkan pada babak serangan ke atas penduduk kampung oleh penceroboh. Kediaman masyarakat ini diperbuat daripada bahan-bahan hutan seperti batang pokok, daun mengkuang atau pelepah. 
Sementara itu, rumah Tombiruo dan Pondoluo pula dibina di atas pokok. Rumah ini juga menggunakan hasil hutan sepenuhnya. Rumah ini didirikan di atas pokok dan tidak mempunyai tiang. Pokok besar dijadikan tiang bagi rumah mereka. Lantai rumah pula diperbuat daripada papan dan juga buluh. Atapnya pula diperbuat daripada daun mengkuang. Separuh daripada dinding rumah ini diperbuat daripada buluh dan separuh lagi diperbuat daripada daun rumbia. Rumah pokok ini juga memiliki tempat bersantai umpama anjung. Rumah kediaman yang dibina oleh Tombiruo dan Pondoluo telah menunjukkan bahawa mereka telah memiliki kearifan lokal dan menjadi budaya mereka yang tiada bezanya dengan masyarakat asli di kawasan tersebut.

\section{Watak dan Perwatakan}

Terdapat beberapa watak dalam filem $T P R$ yang menunjukkan hubungan akrab dengan alam. Hal ini dipaparkan menerusi watak protagonis dan sampingan, iaitu Tombiruo, Tobugi, Monsiroi, dan Pondolou. Hubungan alam dengan keempat-empat watak ini sangat akrab kerana alam merupakan tempat tinggal dan sumber untuk mereka meneruskan kehidupan. Segala keperluan hidup seperti pakaian, tempat tinggal, peralatan, makanan, dan bahan perubatan diperolehi daripada alam. Kesedaran tentang kebergantungan mereka kepada alam, menyebabkan watakwatak ini amat menghormati dan memuja semangat alam dengan berusaha menjaga, melindungi, dan melestarikan alam tanpa mengharap sebarang balasan.

Watak pertama yang memperlihatkan hubungan akrab dengan alam adalah Tombiruo. Tombiruo merupakan watak utama atau protagonis yang menerajui filem ini. Watak ini dipaparkan sebagai seorang pemuda yang berumur dalam lingkungan 30-an. Watak ini juga memiliki tubuh badan yang sasa dengan wajah yang tidak sempurna. Kecacatan wajah Tombiruo menakutkan sesiapa sahaja yang melihatnya. Untuk menyembuyikan kecacatan ini, maka watak ini dipakaikan topeng. Selain itu, Tombiruo juga dianggap sebagai penunggu hutan atau pelindung bagi masyarakat Kadazan Dusun di Sabah. Bagi orang luar atau bandar, Tombiruo dianggap sebagai entiti negatif.

Tombiruo sebenarnya adalah watak manusia yang dilahirkan, dibesarkan dan menghuni Hutan Keningau. Jiwa Tombiruo sebati dengan kehidupan di hutan (Ramlee Awang Murshid, 2018). Sejak dilahirkan, Tombiruo tidak pernah meninggalkan persekitarannya. Hal ini kerana, Tombiruo diamanahkan oleh bapanya untuk menjaga keamanan hutan Keningau daripada pencerobohan asing. Segala keperluan untuk meneruskan kehidupan diperolehi daripada sumber alam disekelilingnya. Oleh itu, Tombiruo sangat akrab dengan alam. Keakraban watak Tombiruo dengan alam juga memberi kesan yang besar terhadap kehidupannya sehingga dia mahir dengan segala ilmu yang berkaitan alam. Antara kemahiran watak ini adalah kecekapan bergerak dalam hutan, kepakaran membuat tempat tinggal dan senjata dengan menggunakan bahan daripada hutan, ilmu berburu, dan ilmu pelbagai kegunaan tumbuhan hutan. Kemahiran ini telah dilatih oleh bapanya Pondolou sejak kecil lagi bagi memenuhi keperluan masa hadapan watak ini. 
Tombiruo adalah simbol kepada kesan pengkhianatan manusia terhadap alam. Dalam erti kata, Tombiruo diibaratkan anak kepada alam yang telah dinodai. Tombiruo adalah hasil daripada perbuatan jahat Tarawid terhadap Tobugi. Perbuatan Tarawid itu telah menyebabkan Tobugi melahirkan anak haram yang tidak berwajah manusia. Monsiroi yakin bahawa kelahiran anak yang tidak berwajah manusia tersebut adalah kesan daripada salah laku Tarawid. Ia adalah satu petanda tidak baik bagi masyarakat mereka. Justeru, untuk menebus dosa Tarawid dan memastikan kestabilan ekosistem masyarakat pedalaman di hutan Keningau terjaga, maka denda ritual atau 'pampasan yang menyejukkan' (sogit) perlu dilakukan terhadap kesalahan yang dilakukan oleh Tarawid. Oleh itu, Monsiroi telah mengembalikan bayi tidak berwajah manusia kepada alam sebagai sogit untuk menebus kesalahan Tarawid.

Selain mewakili simbol pengkhianatan manusia terhadap alam, Tombiruo juga merupakan simbol kepada kekuatan alam. Watak ini mempunyai kuasa luar biasa untuk mengarah dan mempengaruhi alam serta membantunya ketika dalam bahaya. Kuasa luar biasa yang dimiliki Tombiruo membolehkannya mengawasi tindakan manusia di hutan Keningau. Tombiruo akan mengusir keluar mana-mana individu yang memasuki hutan Keningau dengan niat jahat. Tombiruo tidak akan teragak-agak untuk menggunakan kekasaran jika pihak lawan bertindak kasar dan mengingkari arahannya.

Tombiruo juga sangat dihormati oleh masyarakat sekeliling kerana kuasa luar biasanya. Hal ini sinonim dengan kepercayaan masyarakat Kadazan-Dusun di Sabah bahawa semangat alam harus dihormati, sekiranya tidak alam akan bertindak ganas terhadap mereka. Malapetaka akan menimpa kehidupan mereka, dalam sebarang bentuk kecelakaan, termasuk wabak yang membawa kematian (Pugh-Kitingan, 2016). Hal ini juga turut berlaku dalam filem $T P R$, apabila watak jahat Juslan dan Wong yang berniat jahat terhadap alam, mati dalam keadaan yang mengerikan. Juslan meninggal dunia akibat terjatuh dalam rekahan tanah dengan "kuasa alam" dimiliki oleh Tombiruo, manakala Wong cedera akibat ditimpa sebatang pokok ketika berlawan dengan Tombiruo. Ini jelas menunjukkan bahawa alam telah menghukum kedua-dua manusia yang berniat jahat terhadapnya.

Watak kedua yang memperlihatkan hubungan akrab dengan alam adalah Tobugi. Watak Tobugi dipaparkan sebagai seorang gadis sunti yang tinggal di daerah hutan Keningau, Sabah. Watak ini dinodai kesuciannya oleh Tarawid dan dia melahirkan anak kembar, Tombiruo dan Amiruddin. Selepas melahirkan anak kembar, Tobugi telah meninggal dunia. Tobugi adalah simbol kepada tanah yang dirosakkan oleh manusia. Dalam konteks alam, kerosakan tanah ini berpunca daripada sifat rakus manusia yang melakukan pembalakan haram dan pembakaran secara terbuka sehingga menyebabkan berlakunya hakisan tanah serta tanah runtuh. Manusia sepatutnya bertindak memelihara dan menjamin kesejahteraan alam yang mereka diami. Mereka tidak sepatutnya bertindak rakus demi kepentingan peribadi dan menyebabkan kemusnahan. Tawarid berlaku jahat apabila mencabuli kehormatan dan maruah diri Tobugi. Perbuatan sumbang Tarawid mengakibatkan Tobugi melahirkan anak kembar dan salah satunya tidak berwajah manusia. Ini jelas menunjukkan bahawa watak Tobugi merupakan simbol kepada alam yang dirosakkan oleh manusia yang rakus. Perbuatan merosakkan ini mengakibatkan kesan negatif terhadap alam, iaitu kelahiran Tombiruo yang tidak sempurna. 
Watak ketiga yang memperlihatkan hubungan akrab dengan alam adalah Monsiroi. Monsiroi merupakan watak sampingan yang menonjol dan penting berbanding watak sampingan yang lain. Watak ini dipaparkan sebagai seorang wanita yang berumur dalam lingkungan 70 -an. Sebagai Bobolian, watak ini bertindak sebagai dukun bagi masyarakat Kadazan-Dusun di Sabah. Hal ini jelas apabila Monsiroi menjadi bidan untuk membantu kelahiran Tombiruo dan Amiruddin. Selain itu, Monsiroi juga turut berperanan menjaga dan merawat Tobugi sepanjang kehamilannya. Watak ini juga menjalani kehidupannya di hutan Keningau. Hubungan alam dengan diri Monsiroi sangat akrab dan watak ini juga tidak pernah meninggalkan hutan tersebut.

Watak Monsiroi berfungsi sebagai agen pendamai antara alam dengan manusia. Monsiroi mengambil tanggungjawab mententeramkan keadaan dan mengembalikan kestabilan ekosistem apabila anak kembar luar nikah dilahirkan oleh Tobugi. Kerosakan yang dilakukan oleh Tarawid terhadap Tobugi, pembunuhan Tawarid, kematian Tobugi dan kelahiran anak kembar luar nikah itu harus ditebus. Kerosakan yang dilakukan ke atas alam, harus ditebus supaya kehidupan kembali tenang dan terkawal. Monsiroi mengambil keputusan membayar sogit. Monsiroi bertindak demikian untuk mententeramkan alam supaya tidak berlaku sebarang bencana yang tidak diingini. Perbuatan Monsiroi ini telah menjamin keharmonian antara alam dengan manusia.

Watak Monsiroi juga adalah agen penyatuan atau penghubung antara manusia dengan alam. Peranan watak ini penting kerana manusia dan alam perlu bersatu dan harmoni supaya tidak berlaku sebarang krisis yang membawa kepada kemusnahan. Fungsi watak Monsiroi adalah untuk menyatukan hubungan manusia dengan alam melalui interaksinya dengan alam ghaib. Hal ini jelas dalam filem $T P R$, apabila Monsiroi bertindak menyatu dan mengamankan watak adik-beradik kembar Tombiruo dan Amiruddin yang terpisah lebih 31 tahun. Monsiroi berjaya meleraikan pergelutan antara adik beradik kembar tersebut dengan ilmu dukunnya. Monsiroi mengeluarkan uri Tombiruo dan Amiruddin serta memanggil roh Tobugi untuk membawa cinta dan kebaikan di antara mereka. Selepas Monsiroi menjelaskan sejarah dan hubungan adik- beradik kembar tersebut dan mereka berdamai. Monsiroi berjaya menamatkan krisis antara alam yang diwakili oleh Tombiruo dengan manusia yang diwakili oleh Amiruddin dalam konteks ini. Sesuai dengan peranannya sebagai Bobolian, iaitu perantara alam ghaib dengan manusia.

Watak keempat yang memperlihatkan hubungan akrab dengan alam adalah Pondolou. Watak sampingan ini juga penting dalam ekosistem yang dipaparkan dalam filem TPR. Pondolou dipaparkan sebagai seorang bekas askar British yang berumur dalam lingkungan 60-an. Watak ini menemui Tombiruo sewaktu bayi di sungai ketika umurnya sekitar 30-an. Watak ini merupakan bapa angkat kepada Tombiruo. Perwatakan Pondulou dipaparkan sebagai bertanggungjawab, berani, baik hati, dan pandai berdikari. Selain itu, watak ini juga turut dipaparkan mahir dalam ilmu yang berkaitan alam seperti ilmu berburu, mengenali pelbagai tumbuhan hutan untuk kegunaan seharian, membuat sendiri segala keperluan kehidupan seperti pondok kediaman, dan senjata berburu. Berbekalkan ilmu ini Pondolou mampu hidup di dalam hutan Keningau lebih 30 tahun sehingga jiwanya sebati dengan kawasan serta kehidupan di hutan tersebut.

Watak Pondolou dalam filem TPR mewakili pengabdian manusia terhadap alam. Pondolou melindungi dan menjaga kelestarian hutan Keningau daripada sebarang ancaman serta kerosakan oleh manusia yang rakus. Pengabadian Pondolou terhadap alam juga menyebabkan dia sanggup 
memelihara Tombiruo, sekalipun bayi yang ditemuinya memiliki wajah yang menakutkan. Pondolou menjaga dan membesarkan Tombiruo seperti anaknya sendiri sehingga sanggup mengorbankan nyawanya bagi melindungi Tombiruo ketika pencerobohan terhadap masyarakat pedalaman Hutan Keningau. Hal ini jelas menunjukkan bahawa pengabadian diri Pondolou terhadap alam melebihi dirinya sendiri sehingga sanggup merawat, menjaga, melindungi, dan melestarikan alam tanpa mengharap sebarang balasan.

\section{Kesimpulan}

Filem TPR adalah sebuah filem dengan mesej advokasi terhadap alam. Selain berlatarbelakangkan alam pada hampir keseluruhan filem, subjek penceritaannya juga berkait dengan hubungan alam dan manusia. Filem ini memaparkan kesan tindak tanduk manusia terhadap alam dan keperluan manusia menjadi pelindungnya. Manusia dan alam terangkum dalam ekosistem alam semulajadi. Manusia harus hormat dan melindungi alam agar keharmonian ekosistem terjamin. Sekiranya manusia gagal melindungi alam, maka kebinasaan dan malapetaka akan menimpa. Filem TPR secara tersirat turut menyampaikan mesej ini melalui watakwatak utama dan watak sampingannya. Watak Tombiruo adalah watak protagonis dalam filem ini dan mewakili semangat alam, iaitu kepercayaan masyarakat pedalaman di Sabah. Alam yang dinodai manusia diberi perwatakan manusia untuk melindungi diri dan membalas kejahatan manusia yang rakus.

\section{Rujukan}

Astro Awani. (November, 2017). Tombiruo: Penunggu rimba kutip RM8 juta, jadi filem kedua terlaris 2017. Retrieved from https:/www.astroawani.com/berita-hiburan/tombiruo-penunggu-rimba-kutip-rm8-juta-jadi-filem-kedua-terlaris-2017-160483.

Ahmad Zamil Zakaria, Ismail Hafiz Salleh, \& Mohd Sabrizaa Abd. Rashid. (2013). Malay landscape elements as depicted in the old Malay films. Jurnal Pengajian Melayu/Journal ofMalay Studies (JOMAS), 24(1): 122-137.

Bosselmann, K. (1999). When two worlds collide: Society and ecology. New England: RSVP Publishing.

Eckersley, R. (1992). Environmentalism and political theory: Toward an Ecocentric approach. New York: State University of New York Press.

Hani Salwah Yaakup. (2018). Adaptasi novel ke filem dan representasi kepercayaan setempat. Jurnal Komunikasi, 34 (2): 323-337.

Kerajaan Negeri Sabah. (2020). Retrieved from http://www.sabah.gov.my/cms/?q=ms/content/rakyatsejarah laman web rasmi kerajaan negeri sabah.

Low Kok On. (2005). Membaca mitos dan legenda Khadazandusun. Bangi, Selangor: Penerbit Universiti Kebangsaan Malaysia.

Malay Mail. (2017). 'Tombiruo': The new yardstick for the local film industry. Retrieved from https:// www.malaymail.com/amp/news/showbiz /2017/09 /27/tombiruo-the-new-yardstick-for-the-local- 
film-industry/1474479.

Minah Sintian. (2013). Kepercayaan dan amalan masyarakat Kadazandusun dalam pemeliharaan alam sekitar. Januari 2013. Conference: Persidangan Intelektual Kebangsaan Malaysia. Retrieved from https://www.research gate.net.

Mohd Azlan Abdullah. (2003). Pembinaan Projek Hidro Elektrik Bakun di Belaga Sarawak: Beberapa kesan awal terhadap perubahan fungsi Pekan Belaga serta penduduk downstream Bakun September 2003 Conference: Persidangan Kebangsaan Pusat Pengajian Sosial, Pembangunan \& Persekitaran "Cabaran Pembangunan, Dilema Persekitaran" 12-13 September, 2003 UKM Bangi. Retrieved from https://www.researchgate.net.

Naque Ariffin. (2017). Nota Kaki untuk Filem Tumbiruo: Penunggu Rimba. Retrieved from http://naqueariffin.blogspot.com/2017/10/nota-kaki-untuk-filem-tombiruo-penunggu.html.

Nina Farzuin. (2014). Karangkraf terbit filem: Novel popular Tombiruo karya Ramlee Awang Murshid bakal ke layar perak. Sinar, Disember, 6.

Nur Aifaa Nabilah Mohd Rosdi, Nur Afifah Vanitha Abdullah \& Fatimah Muhd Shukri. (2020). Proses transformasi naratif daripada novel ke filem dalam filem Tombiruo: Penunggu Rimba (2017). Jurnal Melayu, Isu Khas Disember.

Pugh-Kitingan, J. (2016). Siri etnik Sabah ITBM-UMS: Khadazan Dusun. Kuala Lumpur: Institut Terjemahan dan Buku Malaysia.

Ramlee Awang Murshid. (2018). Tombiruo: Penunggu rimba. Shah Alam, Selangor: Buku Prima.

Shazyrn Mohd Faiz. (2017). Tumbiruo Penunggu Rimba Meleret tapi Okay! Retrieved from https://www.mstar.com.my /spotlight/wayang/2017/10/26/ tombiruo.

Suraya Sintang. (2003). Penganutan Agama Islam dan Kristian di kalangan masyarakat Kadazandusun Di Sabah. Retrieved from ejournal.um.edu.my.

Syanty Octavia Amry. (2017). Beraksi dalam hutan. Retrieved from https://www.hmetro. com.my/utama/2017/09/267779/beraksi-dalam-hutan.

Tombiruo: Penunggu rimba. (2017). Filem Aksi Seram. Malaysia: Astro Shaw. 